\title{
豪雪地スギ林の雪害発生条件に関する研究 (I)
}

\author{
北村 昌美・今永 正明*
}

\begin{abstract}
要 旨
豪雪地带に括けるスギ林の雪害発生条件を検討する基礎資料として，1959年に植栽された 0.52 ha の林分 の，1965年から1975年に至る雪害発生経過を調べた。

この間に発生した致命的な雪害は, 総本数 1,055 本の5ち580 本に及んでいる。このほかに被圧のため伐

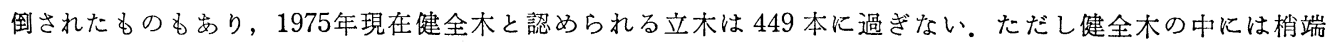
折れなどの軽度被害の立木が含まれる。

被害は豪雪年に激発して扣り。被害木の多くは谷の部分と急傾斜の部分に分布するという傾向が認められ
\end{abstract} る.

\section{1. はじめに}

豪雪地帯に植栽されたスギは，樹幹の根元付近に発生 する折れ被害や割れ被害などのために致命的な損傷を受 けることが多く，はなはだしい場合には林分が大部分破 壊されて成林不能となってしまう。

この雪害発生条件や発生機構の解明のために，これま で多くの研究が行なわれてきたが，注とんど雪害の多発 した一時点における検討にとどまり，植栽から成林に至 るまでの被害の全容を知るには不十分であった。雪害発 生の直接の原因である積雪の条件が年によって異なり, その上立木はまた年を追って大きさと形を変え, 林分構 造も次第に変化して行く.このことによって生じる積雪 と立木の相互関係の変化を, 総合的に検討しなければな らぬことは明らかである。

筆者らは山形大学演習林内にいくつかの固定研究林分 を設定し, 被害発生経過と林分の生長経過を追跡するこ とによって, 豪雪地スギ林の雪害発生条件の解明を試み た. 本報はそのらちの一林分に発生した被害経過追跡結 果の総括である.

\section{2. 研究の場所}

研究の場所は, 山形大学演習林 (山形県東田川郡朝日 村） 1 林班ち小班内に設定した面積 0.52 ha の第 1 研究 林分である. 本林分のスギは1959年植栽で, 研究林分設定 の1965 年には1,055本が生立していた．林分の形状と立 木分布は図 1 に示すとおりであり，海抜 $380 \mathrm{~m}$ から $430 \mathrm{~m}$ の範囲に位置している. 最大積雪深の平均は約 $2.5 \mathrm{~m}$ で
ある。

本林分の上方（北）緩斜面汇は1912年植栽のスギ老路

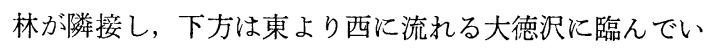
る、北西汇隣按する緩斜地のスギ林（1952年植栽）を越 兄, 冬季の主風が研究林分内吹き达を. 急傾斜の本林 分と, 上方潾接するスギ林分の間㑔㖽泠変換線がある ため，吹き込えだ風は本林分内で乱流を起こすのではな いかと推測される。

\section{3. 研究の方法}

(1) 立木の測定

a ) 立木位置の測定

1965年当時の生立木すべてについて，池際点（幹軸と 地面の交点) の位置を, 紛座標横座標とも $10 \mathrm{~cm}$ 単位 で測定し，立木位置図を作成した。な括侮木に立木番号 をつけ，継続測定が可能なようにした。

b ）立木の大きさと形状の測定

立木の胸高值径 ( $2 \mathrm{~mm}$ 単位), 樹高 $(0.2 \mathrm{~m}$ 単位, 1975 年は $0.5 \mathrm{~m}$ 単位) 1965 年以降 5 年ごと飞测定し， 根元曲りの状態を表わす尺度としては㖽幹幅を同梯に 5 年ごとに測定した。ここで傾幹幅とは, 地際点に立てた 垂線の地上 $1.2 \mathrm{~m}$ (胸高) の点から幹軸点での水平距離 である.この测定単位は, ぞのような括約幅にも対応で きるよう $1 \mathrm{~cm}$ とした。

\section{c) 被害の測定}

被害の測定は每年融雪直後に行ない, 被害木について は地際点から被害部までの幹長 ( $0.1 \mathrm{~m}$ 単位), 被害部の 直径 ( $2 \mathrm{~mm}$ 単位) を可能な限り測定するょうにした。 ただし1975年春までの被害木については, 根元直径 (2

*山形大学農学部 
万向), 樹幹長その他計測可能な 各種の 測定值が求めて ある.

被害の種類については, 従来の分類にしたがって記載 するとともに, 被害程度を次の 3 段階に区分して記載し た.

$\mathrm{A}$ ：回復可能とみなされる程度.

B : 生存可能ではあるが, 回復しても被害の後遺形態 を残すとみなされる程度。

C：立木全体が回復不能，あるいは少なくとも被害部 より先が生存不能とみなされる程度.

ただしこの区分は被害調査時の判断によるものである から，かならずしもその後の現実の経過とは一致しない し，それぞれの段階を分ける明確な尺度もない。

d）被害後の経過の测定

被害調査と並行して，過去の被害木のそれぞれにつき 被害後の経過を測定した。被害程度がAからBへ，ある いはBからCへ進むもの，枯死するもの，伐倒されるも のなどがある一方で, 回復に向から立木もある. 回復之 判断する場合, その内容には次の 3 通りが考えられる.

1）被害の痕跡が認められなくなったもの.

2）屈曲や曲りなどの後遺形態を残してはいるが，損 傷そのものは回復しているもの.

3）折れ被害の場合，損傷は回復してはいないが，側 技あるいは腋芽が主軸に代って生長しているもの.

被害木の再被害もしばしば見受けられるが，これにも 樹幹そのものに被害がある場合と，上記の 3 ）の側枝や 腋芽が損傷を受ける場合の雨方がある。

(2) 地形の測定

レベルを用いて新たに水準測量を行い，200 分の 1 の 図上に $1 \mathrm{~m}$ の等高線を入れ地形図を作成した。次に毎木 の地際点を中心として半径 $5 \mathrm{~m}$ (図上で $2.5 \mathrm{~cm}$ ) の円 を描き，これらの円について等高線から次の 5 要因を読 み取った.
1) 平均傾斜角：最大傾斜方向の直径と交わる等高線 の数より测定 ( ${ }^{\circ}$ 単位).

2）上下傾斜角の差 : 立木の上方々下方の最大傾斜角 を 1）と同様に求め, 下方傾斜角上り上方傾斜角を 引いた値 ( $1^{\circ}$ 単位). したがってこの值が正の場合 は局部的上昇斜面, 負の場合は局部的下降斜面.

3) 地形曲率 : 地際点を通る等高線を想定し, この等 高線と円との交点によってできる中心角のうち, 谷 側のものの值 $\left(10^{\circ}\right.$ 単位). したがって $180^{\circ}$ を越兄 れば凸形斜面 (小尾根)， $180^{\circ}$ より小さい場合は凹 形斜面 (谷), $180^{\circ}$ 前後なら平衡斜面.

4) 傾斜方位：地際点を通る最大傾斜線の方位 $\left(10^{\circ}\right.$ 単位).

5）比高：演習林の石標 No.54 を基準点とし，これ との高低差 (0.1m単位).

（3）精雪の諸性質の測定

積雪深は1965年以降月 2 回, 後には週 1 回, 研究林分

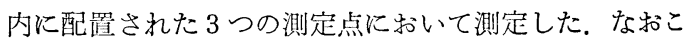
のほかに，不定期ではあるが $5 \mathrm{~m}$ の距離と間隔で積雪 深， $10 \mathrm{~m}$ の距離と間隔でラムゾンデによる硬度測定など を行った。ただし積雪の諸性質については続報において 取り扱らこととする。

\section{4. 研究の結果と考察}

\section{(1) 雪害発生経過}

総本数 1,055 本のうち，1965年以降1975年までの被害 種類別本数を総括すれば表 1 のようになる．表 1 は既発 䘚のデータ（今永・北村，1976）のらち1975年ならびに 発生年不明の被害本数を, 後の観察をもとにして一部訂 正したものである. 豪雪地の雪害としてはふつら致命的 とは考学られない梢端折れと，根抜けのらち前述の被害 程度AあるいはBの立木はこの中から除き，重度被害， すなわち根抜けC拈よび割れ折れの被害本数を示した。 被害が同一立木に重複して生じた場合は，その立木にと

表 1 スギ幼粭林（1959年植栽，0.52 ha，1,055本）の雪管経過

\begin{tabular}{|c|c|c|c|c|c|c|c|c|c|c|c|c|}
\hline 被致 & $' 65$ & '66 & $' 67 \cdot 68 '$ & 69 & 70 & 71 & $' 72$ & $' 73$ & $' 74$ & 75 & (年不明) & 計 \\
\hline 根 拔 & & 6 & 12 & 1 & 6 & & & & & 8 & 1 & 34 \\
\hline 幹 割 & & & 8 & 6 & 8 & 2 & 3 & & 6 & 1 & & 34 \\
\hline 根元割 & & & 21 & 24 & 25 & 3 & 4 & 4 & 168 & 20 & 4 & 273 \\
\hline 幹 折 & 1 & 3 & 12 & 8 & 22 & 3 & 4 & 7 & 20 & 6 & & 86 \\
\hline 根元折 & & 4 & 21 & 13 & 14 & 1 & 1 & 1 & 68 & 11 & 2 & 136 \\
\hline その他 & & 3 & 3 & 3 & 2 & & 1 & 1 & & 3 & 1 & 17 \\
\hline 計 & 1 & 16 & 77 & 55 & 77 & 9 & 13 & 13 & 262 & 49 & 8 & 580 \\
\hline
\end{tabular}

杪端被害と軽度の根抜被害を除く，重複被害は症状の重い力に分類 
表 25 年間の被害状態の推移

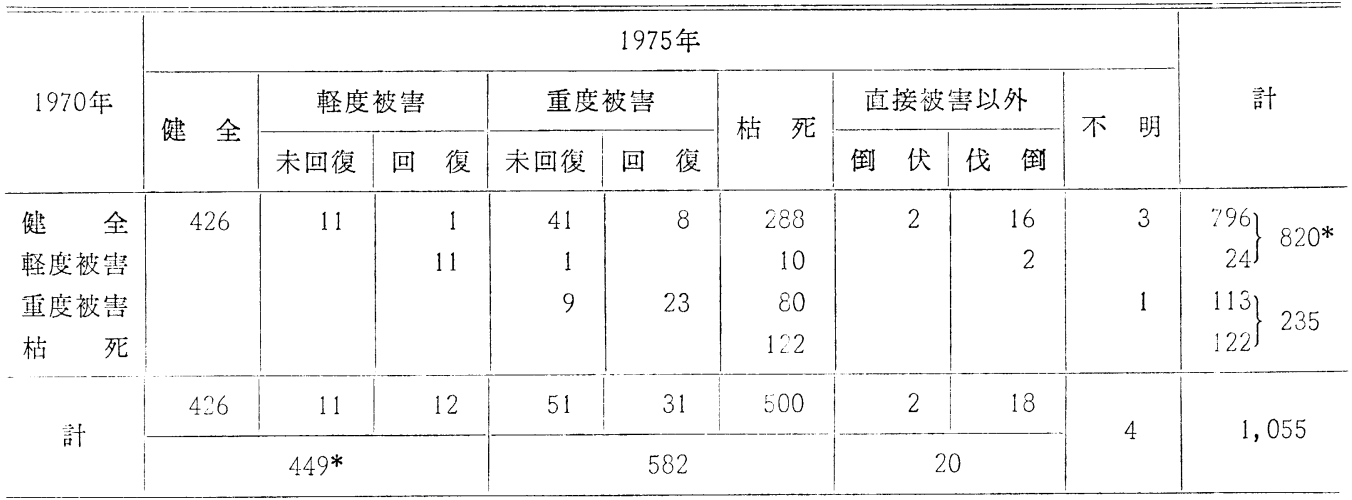

*解析の際に健全木として取り扱う本数

って致命的と思われる方をとって分類した。 その際原則

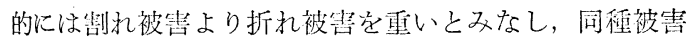
の場合には前述の被些区分の順序にしたがったが，最終 的な判断は被埳後の経過観察にもとついて下した，根抜 けは割れならびに折れよりも軽いとしたが，これも被害 後の経過を判断の根拠としたのでかならずしも一般的で はない。

その他の被㫪に分類されているのは，融雪の祭に泥水 をかぶったものが大部分であるが，中には原因不詳のも のも含まれる。

なお発生年不明とあるのは，留畫を受けた华にてれに 気付かず，後の㗈查の際に発見されたものである。根抜 けの多くはこれに該当するとい完るが，少々の或机はあ

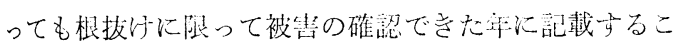
ととした。

幹折れ被踷の中には明らかに冠雪書とみなされるもの があり,これらの多くは前述のよらに側枝あるいは腋芽 による回復が可能である。表 1 の幹折れ本数のらち明ら かに冠雪害とみられるものを示せば，1969年が 2 本，70 年13本，71年と73年がそれぞれ1本となる。

被害木本数は年によって著しく異なり，特に豪雪年で あった1974年には激增している。このことは既報にも触 れたと招りであるが(北村，1975)，そらかといって積 雪量が雪㫪発生条件のすべてでないのはもちろんであ る. 連繶的要因（北村，1975）としての立木の大きさと その変化, 林分構造の推移, 地形などと, 偶発的要因 （北村，1975）としての積雪の諸性質との間にある関係 を, 総合的に解析する必要のあることはいらまでもな い.この解析は続報において行なら。

\section{(2) 被害後の経過}

被害状態を表 1 に示した重度のものとその他の軽度の

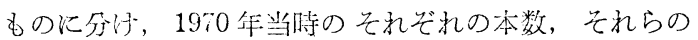

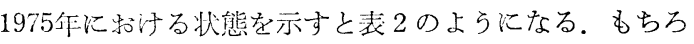
ん枯死木は重度被害の結果で, 伐倒木とともにこれを重

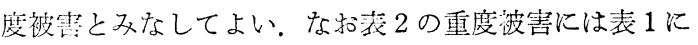
示したもののほかに梢端折れ 3 本が含をれており, 逆に 1965年には翰折水 1 本をその症状からみて健全木として 取り扱ったので，健全木扱いの立木は当初の 1,055 本か ら1970年には820本，1975年には449本に激減したことに なる。

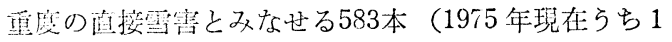
本が不呵不）の实かに，主として被圧による倒木と伐倒 木，ならびに不时木があり，これらを間淁的な雪害とみ なして被齿术に含和ば，1975年の健全木は当初本数の わずかに42.6\%に過ざず，これに重度被茟からの回復木 を加壳ても，合計 480 床，45.5\%である。

重度被篦からの回復は侧枝方るいは腋芽によるものが 多い，特に则らかに冠雪害と思われる17本については， 重複被䡒を受けた 8 本を除いた 9 本のらら 5 本がこの種 の回復木である。ただしこれら新しい主沙が再び折れ被 害を受けることもしばしばあるので，真に回復とみなせ るか否かについてはな特継繞観测が必要である。

1975年当時の林分被害状態を示せば図 1 のと打りとな る. 1965年の研究林分設定当初, 寸で林分はかなり不 均質となっているが，その後の被㫪によりさらにその不 均質さの進んでいることを, 図 1 より明らかに読み取る ことができる。

\section{(3) 林分の生長}

図 2〜4 は1965年より1975年に至る 5 年ごとの胸高直 径, 樹高, 傾幹幅の分布である.

平均胸高直径は 1965年の $3.04 \mathrm{~cm}$ から70年の 6.75 $\mathrm{cm}$ を経て75年の $11.22 \mathrm{~cm}$ に生長しているが, 被害木 


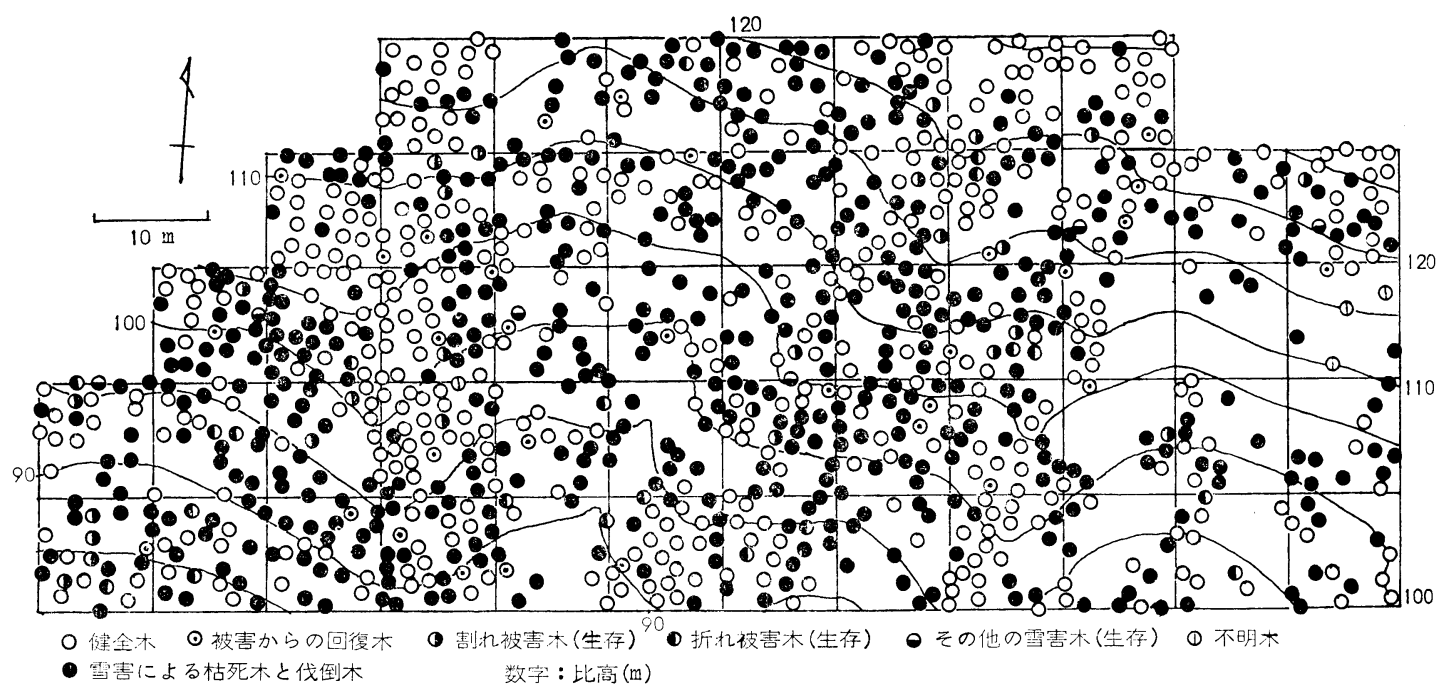

図 1 1975年に扣ける第 1 研究林分の被害状沉
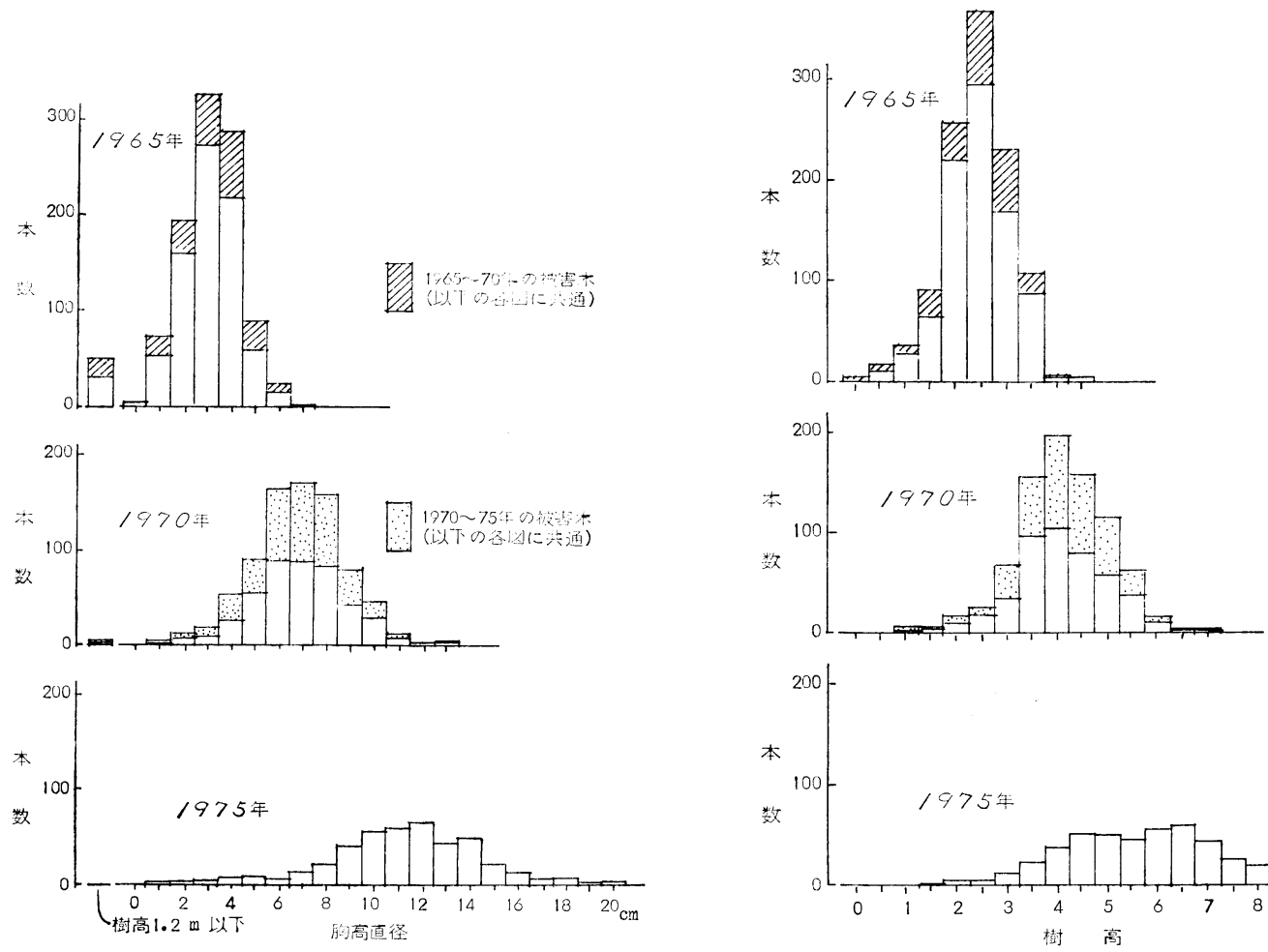

図 2 胸高直径别本数分布の推移

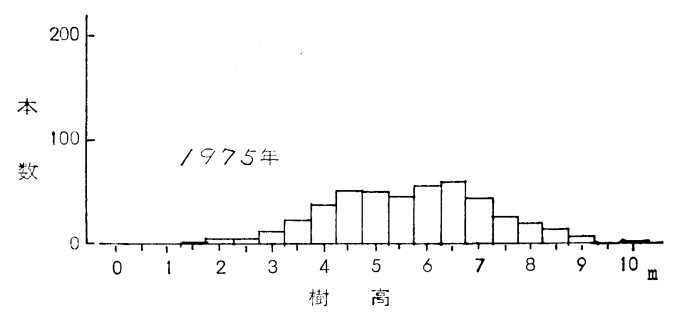

図 3 樹高別本数分布の推移

の直径分布と健全木の直径分布の間にはほとんど差が見 られない、樹高についてもほぼ同様である。ただし假幹 幅の場合は1970以降に多少の差が認められる。すなわち 1970年当時の傾幹幅分布のうち，1975年の健全木の平均 が0.97m，それに対し被害木の平均は $1.07 \mathrm{~m}$ となり差は $10 \mathrm{~cm}$ となる。なお1975年の傾幹幅に見られる異常に大 きな值は，未確認ではあるが恐らく根抜けに起因するす のであろら。これらの今後の良好な生長は期待し難いよ 

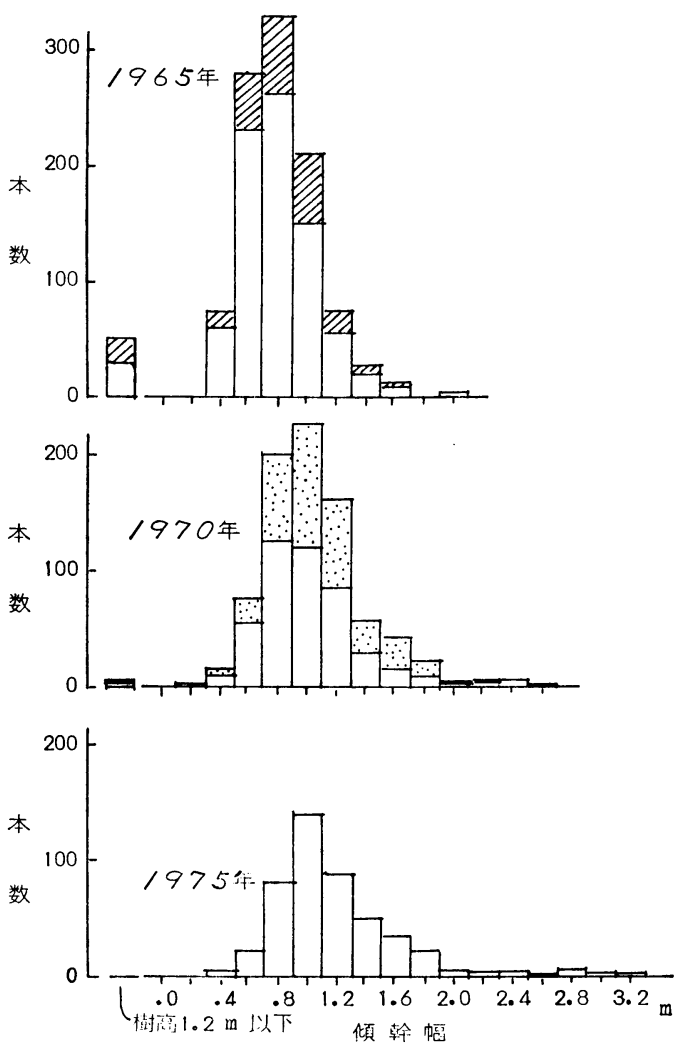

図 4 傾㣮幅別本数分布の推移

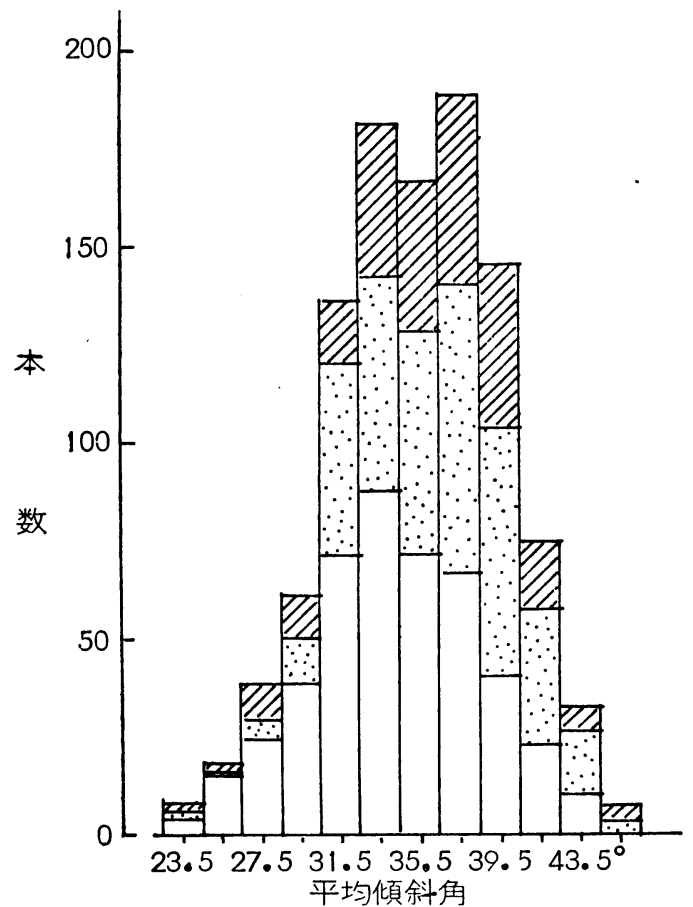

图 5 平均傾斜角別本数分布の推移

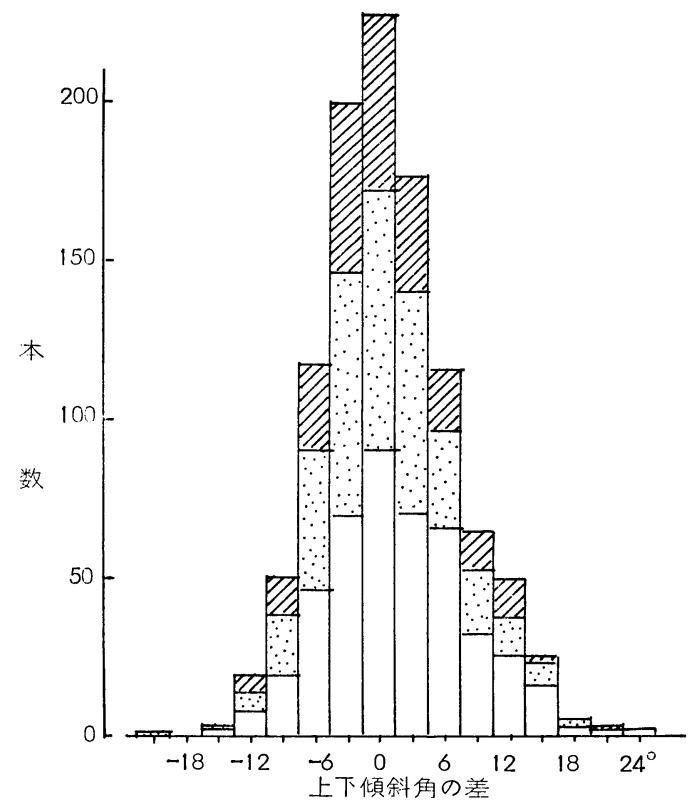

図 6 上下傾斜角の差別本数分布の推移

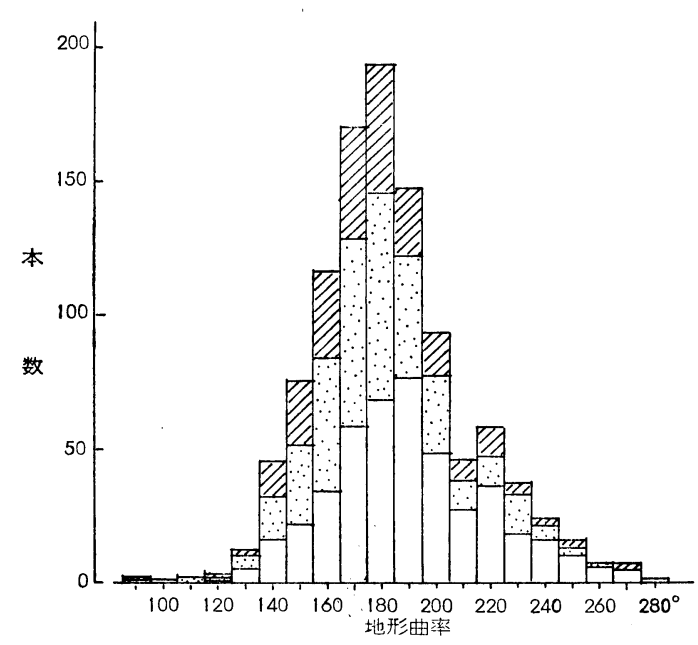

図 7 地形曲率別本数分布の推移

らに思われる。

（4）地形諸要因と雪害の関係

本報においては，個々の地形要因と雪害の関係を概観 するにとどめる。図 $5 \sim 9$ は前述の地形 5 要因とそれぞ れ 5 年間の被害木の関係を図示したものであり, 表 3 は 健全木と被害木のそれぞれに対する各要因の平均値を示 したものである.

表 3 によれば, いずれも僅少な差ではあるが, 緩傾斜 の斜面, 局部的上昇斜面, 凸形斜面, 小さい方位角, 高 い比高へと健全木の分布が移って行く傾向, すなわち上 
表 3 健全木・被害木別の各地形要因平均値

\begin{tabular}{|c|c|c|c|c|c|}
\hline & 平均傾斜解 & 上下傾余斗看の差 & 地形曲率 & 傾斜方 位 & 比 \\
\hline 1965 年健全木 & $35.4^{\circ}$ & $+0.9^{\circ}$ & $183.3^{\circ}$ & $\mathrm{S} 6.8^{\circ} \mathrm{W}$ & $104.2 \mathrm{~m}$ \\
\hline 1970年健全木 & 35.2 & +1.1 & 184.9 & $\mathrm{~S} 6.1 \mathrm{~W}$ & 104.3 \\
\hline 1965～70年被害木 & 36.1 & +0.1 & 177.7 & S $9.4 \mathrm{~W}$ & 104.0 \\
\hline 1975年健全木 & 34.2 & +1.8 & 190.1 & S $5.5 \mathrm{~W}$ & 105.3 \\
\hline 1970～75年被害木 & 36.3 & +0.3 & 178.6 & $\mathrm{~S} 6.8 \mathrm{~W}$ & 103.1 \\
\hline
\end{tabular}

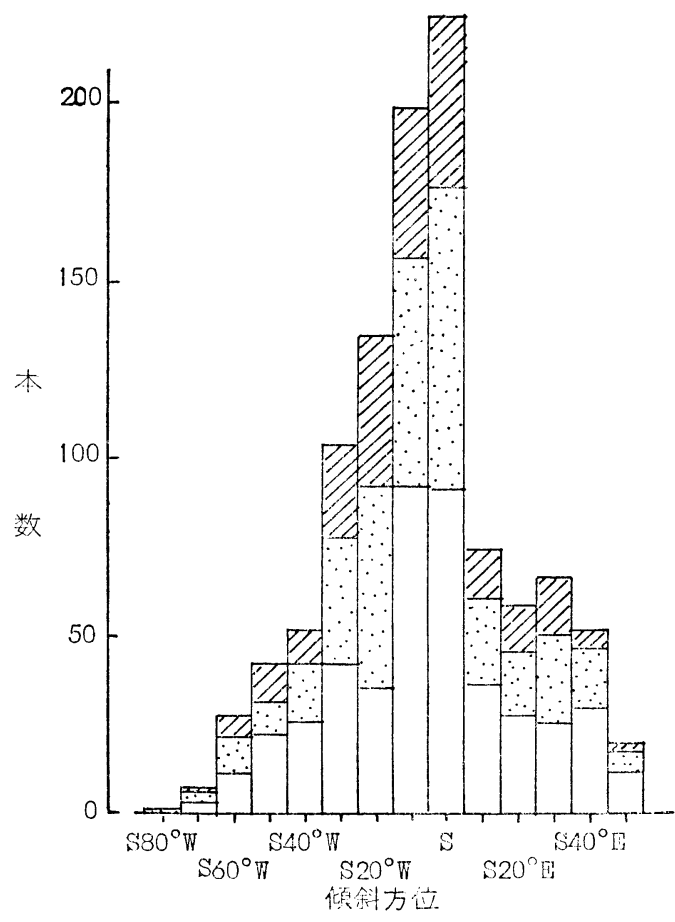

図 8 傾斜方位別本数分布の推䔟

に列挙したのとは近の場所に被害の発生する傾向が涩め られる。その傾向が比較的顕著なのは図 5 の平均傾斜角 と図 7 の地形曲率で, ともに1965年と75年のヒストグラ ムの形にはかなりの差が見られ，それとともにモードの 位置も明らかに移動している。1974年の被害に対して標 本木を用いて行なった解析の場合にも, この 2 要因は傾 斜方位とともに雪害と関係のあることが指摘されており (今永・北村, 1976), 今後の解析に際して, この 2 要因 には特に注目する必要があるものと考兄られる。ただし いずれの要因にしても, 単独で雪害発生条件を説明する には不十分であろう。

\section{5.あとがき}

本報では雪害発生条件解明のための基礎資料として, 一林分に扣ける雪害発生経過を総括し, 地形要因と雪害

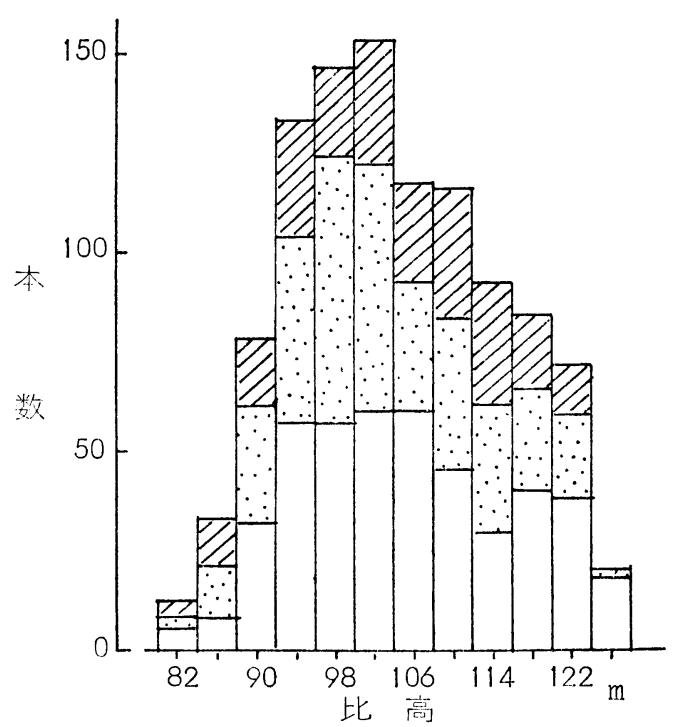

図 9 比高別本数分布の推移

の関倸について予備的な考察を試みた。もともと雪害は 林木を中心とする各種要因の複雑な相互関係の中で発生 するものであるから，単一の要因同士の関係から発生条 件を解明することは困難である。したがって続報に拉い て総合的な解析を行ならとともに，被害の種類による発 生条件の違いについても検討する計画である.

本研究の実施にあたり，山形大学林学科ならびに演習 林の教職員をはじめ, 歴代専攻学生多数の献身的な協力 を仰いだ。また学外における同学の方々の絶えざるご指 導をいただいた。ここに心からの感謝をささげる次第で ある。

\section{文 献}

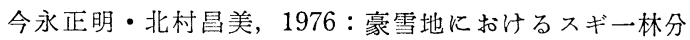
の成林経過々積雪の安定性. 文部省科学研究費, 自然 災害特別研究 (1) 研究報告, 29-32.

北村昌美, 1975 ：スギ幼龄林に打ける雪害発生条件につ いて. 第 12 回自然災害科学総合シンポジゥム論交集, 387-388. 
Studies on the Conditions of the Tree Damage by Snow ( I )

Masami Kitamura and Masaaki Imanaga

(Faculty of Agriculture, Yamagata University, Tsuruoka.)

In order to study the conditions of the tree damage by snow in the heavy-snow area, 1055 trees planted in 1959 on the stand of 0.52 ha have been observed from 1965 to 1975. During the observation period 580 trees had been heavily damaged by snow. In addition, some suppressed trees were cut. Until 1975 only 449 trces remained without heavy damage. Among them, however, some trees slightly damaged at their top parts. It is recognized that the damage is especially severe in the heavy snow year and the damaged trees mainly distribute in the valley and on the steep slope.

(1977 年 5 月 23 日受理) 